I Universidade Federal de Minas Gerais (UFMG),

Departamento de Ciência Política, Centro de Estudos Republicanos

Brasileiros (Cerbras), Belo Horizonte, MG, Brasil

christianbrunoas@gmail.com

Christian Bruno Alves Salles'

\title{
A UTOPIA ANTROPOFÁGICA: RASTOS E HORIZONTES
}

O movimento antropofágico, expressão do modernismo brasileiro, surge em um tempo marcado pela preeminência da temática da identidade nacional na cultura brasileira, incidindo sobre o panorama de controvérsias em torno da definição do caráter da modernidade brasileira, a partir do reconhecimento dos fatores determinantes da originalidade da formação da nação e das formas históricas de sua inserção na civilização ocidental. Uma tensão entre o local e o universal caracterizou o modernismo brasileiro. Tensão que não se traduzia em antagonismo, mas se harmonizava na afirmação da primazia do nacional. Um impulso universalista orientava o movimento, manifesto, sobretudo, na assimilação das vanguardas artísticas europeias. Contudo, a incorporação do dado estrangeiro pressupunha uma reinvenção, por meio da adaptação às condições do meio nacional. Postura, portanto, que não compreendia um rechaço irrestrito ao cosmopolitismo, mas se corporificava na absorção inventiva e crítica do acervo cultural europeu. No âmbito do projeto da antropofagia, a definição do nacional não procedia da mera exaltação da paisagem tropical ou da idealização de traços da cultura. Não era evasivo ou ufanista o olhar antropofágico sobre a realidade brasileira. A indignação ante a ideia de conceber o Brasil como réplica da cultura europeia conduz à necessidade de pensar a existência de uma tradição brasileira no interior da civilização ocidental. A antropofagia oswaldiana representa um itinerário original e audaz, no interior do modernismo e da cultura brasileira, de construção de um discurso e de uma 
realidade no entrecruzamento do nacional e do universal. Roteiro sincrônico de redescoberta do instinto bárbaro de devoração, incrustado no tempo-espaço mítico da originalidade nativa e tornado princípio estruturador de novas formas de vida e expressões culturais conformadoras da nação, no confronto com diferentes matrizes civilizacionais. Não há sentido de redenção de um passado fossilizado por meio de sua restauração plena no presente, mas recuperação de uma força primeva latente, soterrada pelo servilismo político e cultural decorrente de práticas colonialistas. Uma condição propiciadora de uma relação criadora e autônoma com as diferentes tradições e com as conquistas materiais e simbólicas da modernidade.

A antropofagia encerra em seu conteúdo programático um forte componente de emancipação do homem, recorrentemente revelado em imagens utópicas. O nativo que habitava a costa atlântica no momento da conquista europeia fundou comunidades assentadas em formas de vida favorecedoras do livre trânsito de impulsos naturais instintivos, avessas aos imperativos de uma moralidade e de um aparato institucional opressores. Era um reino da igualdade e da liberdade que afinal se constituía, ganhando feições de uma utopia realizada, perdida no passado pré-cabralino. Divisá-la, contudo, não significava nutrir qualquer esperança de restaurá-la no presente. Aquela experiência havia sido irremediavelmente destruída pelas iniciativas de colonização e povoamento do território brasileiro encetadas pelos portugueses. Mas um instinto bárbaro de agressividade e resistência havia sido legado pelo indígena, permanecendo latente na cultura nacional e devendo ser recuperado para deflagrar o combate contra as estruturas valorativas e políticas coloniais ainda vigentes. Essa atitude, em confluência com as transformações geradas por um cenário de acirramento do processo de dissolução dos fundamentos da civilização ocidental, quando as inovações técnicas da modernidade poderiam ser apossadas de forma mais lúdica e criativa pelo homem, abriria caminho ao advento de uma nova era utópica, em um futuro próximo. ${ }^{I}$ Essa é, em linhas gerais, a visão do movimento antropofágico acerca do que se poderia considerar um ciclo utópi$\mathrm{CO}^{2}$ em curso no Brasil, com seus desdobramentos nos dias atuais, a qual se pretende analisar neste artigo. Para tal, serão examinadas as principais referências e elaborações sobre o tema surgidas tanto na Revista de Antropofagia, marco inaugural do movimento, como em certos escritos de Oswald de Andrade, igualmente relevantes para a sua compreensão. Alguns diretamente atrelados à experiência do movimento antropofágico, como o livro Serafim Ponte Grande, cujas páginas guardam imagens utópicas de expressiva significação para a investigação proposta. Outros, embora distantes temporalmente daquela experiência, como os ensaios "A crise da filosofia messiânica" e "A marcha das utopias", revelam consonâncias com as teses antropofágicas, tornando profícua a análise de determinadas reflexões ali presentes que se mostram pertinentes para a realização deste estudo. 


\section{UTOPIA, IMPÉRIO DOS INSTINTOS}

Ágil, impetuoso, o nativo peregrino embrenhado na matéria espessa e igualmente móvel da floresta reúne os atributos primordiais da cultura antropofágica, segundo uma determinada visão de seus costumes e de suas formas de vida. Esparsos nos recônditos da imensidão verde, os habitantes do Brasil pré-cabralino revelavam uma humanidade em estado de natureza. Seus dias transcorriam sem a imposição severa de códigos e hábitos opressores, entraves à corrente de sentimentos e desejos primários, espontâneos. Polígamos, os laços familiares não acarretavam pesadas responsabilidades nem constituíam o núcleo da coesão social. "O indio não era monogamo, nem queria saber quaes eram seus filhos legitimos, nem achava que a familia era a pedra angular da sociedade" (Porque como, I975). Ademais, erguia suas malocas sem conhecimento do regime de propriedade privada da terra e convivia em harmonia, a despeito da ausência de uma autoridade política permanente. Tampouco se dedicava de forma sistemática a atividades produtivas destinadas ao acúmulo de riquezas, entregue ao cultivo de uma vida ociosa. O nomadismo, o feitio das práticas conjugais, as formas de interação social e com o meio refletem a vigência do princípio da "posse contra a propriedade" (Andrade, I975b), a imperiosidade da divisa "só me interessa o que não é meu" (Andrade, I975a: 3), bases de uma espécie de "direito biológico, que admitte a lei emergindo da terra, á semelhança das plantas" (O direito..., I975).

Aqueles povos formavam sociedades calcadas na simplicidade, condição de uma existência alegre e salutar, reagindo com agressividade às intempéries que ameaçavam sua ventura. Suas práticas e habilidades respondiam a impulsos primitivos não apenas de sobrevivência, mas de deleite, em simbiose com o ambiente circundante. A vida operava em função das necessidades do homem enquanto ser biológico:

O indio aprendia a caçar, a pescar, a cultivar a terra, a esgrimir o tacape, a devorar os prisioneiros, a cantar os seus hinos de guerra, a tocar a inubia, a pintar a flora e a fauna. Aprendia os meios, emfim, de se utilizar e de se defender da opulenta e bravia natureza que o cercava (Rezende, I975).

Seu éthos consistia, primordialmente, em se apoderar das forças reconhecidas como benéficas e evitar a interferência de elementos prejudiciais, mortificadores. Sem dúvida, referenciais significativos para a elaboração das diretrizes programáticas do movimento antropofágico:

Todo nosso julgamento obedece ao criterio biologico. A adjectivação antropofagica é apenas o desenvolvimento da constatação do que é favoravel e do que é desfavoravel ao homem biologicamente considerado. Ao que é favoravel chamaremos bom, justo, hygienico, gostoso. Ao que é desfavoravel chamaremos perigoso, besta, etc. (De antropofagia, I975a).

Ressalta o substrato moral, a escala de valores do selvagem, de onde emana o sentido vital igualmente catalisador da operação correlata essencial de transformação do tabu em totem. 
Desponta a altivez da antropofagia ritual praticada pelos Tupi costeiros. Ato sobretudo religioso, festim sacrificial celebrado pela purificação do grupo ofendido em seus brios. Em nada se assemelha a um massacre hediondo, tampouco é encetado para satisfazer um puro desejo de morte ou expressa o hábito inveterado de consumo de carne humana.

Contrapõe-se, em seu sentido harmônico e comunial, ao canibalismo que vem a ser a antropofagia por gula e também a antropofagia por fome conhecida através da crônica das cidades sitiadas e dos viajantes perdidos (Andrade, 20I Ia: I38).

Nada que obscureça a índole aguerrida do nativo, inerente à sua experiência religiosa, no fundo, uma "religião da guerra" (Viveiros de Castro, 20 I I: 2 I2). Movido por um ímpeto de vingança, valor central de seu código de honra, lançava-se contra o inimigo valente, apresado em combate e, após, no banquete canibal, imolado, o corpo espedaçado e moqueado, em meio ao alvoroço do canto e da dança: "a mortandade (êsse carnaval)" (Machado, I975). Irrompe o tempo sagrado da festa, com seu apanágio de ruptura com a dinâmica dos afazeres cotidianos, sob o primado do gasto e da abundância, impelindo ao rejuvenescimento da ordem social: "A economia, a acumulação, a medida definem o ritmo da vida profana; a prodigalidade e o excesso, o da festa" (Caillois, I 979: 5I 2; grifos do autor). ${ }^{3}$ A devoração e consequente assimilação das qualidades do oponente desatam um processo de reconfiguração da identidade e simbolizam a queda do tabu, enquanto resistência do mundo externo, tornado um totem.

Para a antropofagia, a imagem do índio nu, solto na amplidão da floresta, ressalta o inculto, o bruto, remete ao domínio das criações intocadas pelos artifícios da cultura, fonte de pureza e inocência - aspectos de forte significação utópica. Predicados que não denotam uma condição cristã de insciência, ausência de malícia, mas alheamento aos requintes de uma moralidade corrupta. Os aparatos da civilização extraem do homem a dignidade, fazem nascer sentimentos torpes, incutem padrões de comportamento e de solidariedade degradados. Coberto de vícios, perde a espontaneidade e o espírito imaginativo, precursores de uma existência feliz. A roupa é o dogma, são as fórmulas arbitrárias da normatividade social, a falácia do racionalismo demiúrgico, exortando ao sofrimento e ao trabalho exaustivo, pois "suar e penar é se vestir" (Andrade, 20I Ic: 234) Ou, conforme enuncia o Manifesto antropófago: "O que atropelava a verdade era a roupa, o impermeavel entre o mundo interior e o mundo exterior. A reacção contra o homem vestido" (Andrade, I975a: 3). Ao contrário, as expressões existenciais do selvagem "são vivas, vigorosas, autênticas, úteis e naturais; não fazemos senão abastardá-las nos outros a fim de melhor as adaptar a nosso gosto corrompido" (Montaigne, I 996: I95). A reverência aos "cacóetes mentaes da Europa pôdre de civilização" (De antropofagia, I975b) desvirtua, consome seu viço, estiola seu ânimo e o faz surgir estilizado, "de terço na mão" (Costa, I975), "vestido de senador do Império. Fingindo de Pitt. Ou figurando 
nas operas de Alencar cheio de bons sentimentos portuguezes" (Andrade, I975a: 3). Como no ensaio Des cannibales, as fronteiras entre o Ocidente civilizado luminoso e a sombra da selvageria americana deixam de ser nítidas. O mesmo efeito causado, embora com ressalvas, pela hipótese rousseauniana de um estado de natureza povoado por homens "livres, sadios, bons e felizes" (Rousseau, I997: 94), corrompidos com o advento da sociedade civil, ordenada em torno da instauração de um aparato institucional e moral gerador de desigualdade, opressão e discórdia. ${ }^{4}$

Contudo, o movimento antropofágico não pretende esmaecer os traços bárbaros dos costumes nativos, tampouco encontrar eufemismos que amenizem a aspereza do significado primário do termo. O bárbaro, em sua cosmovisão, mas igualmente nas suas propriedades léxicas, adquire positividade. Os seres esquecidos no continente edênico são, de fato, antropófagos, afeitos à guerra. Desponta o canibal pagão e aguerrido, exatamente a nódoa inoportuna que turva a claridade daquele suposto paraíso terreal bíblico: pródigo, venturoso, sempre primaveril, envolto em aragem tépida, salubre, circundado por águas caudalosas e límpidas. "É uma cousa tola e que recommenda mal os que vivem gritando que o indio brasileiro não comia gente. Comia e muito bem comido" (Assumpto..., I975: 5). Não se sustenta, portanto, o mito do "bom selvagem", inocente, terno, meigo, pacífico, qualidades pretensamente advindas de sua vinculação a um estado de natureza. Tampouco há acordo com um mero "canibalismo de palavras", confronto injurioso quase subsumido ao plano discursivo, presumivelmente propugnado por Montaigne (Lestringant, I997). Se o festim antropofágico é tomado como metáfora, o cerne do seu significado repousa na violência do ato. A coragem, a hombridade, a valentia, tanto quanto o ódio e a reação agressiva são virtudes do guerreiro destemido.

A ferocidade e resistência dos selvagens do continente verde são proclamadas, pelo movimento antropofágico, as forças capazes de manter suas propensões utópicas e desencadear o combate contra o império da moral ocidental, devendo ser resgatadas. Os apanágios consoantes à sua pretensa bestialidade e repugnância se transformam nos símbolos solares de uma humanidade liberada. A tacape, repudiaram a cultura europeia ou se fizeram moucos às prédicas dos catequistas, permanecendo fiéis às formas de vida orientadas por demandas instintivas. Preferiam "dançar, beber e cauinar, o que constitui sua ocupação ordinária" (Léry, ı980: I I6; grifo do autor). Ante as hostes rivais, não reconheciam perdão ou reconciliação, proclamando, "contrariamente à doutrina cristã, que os novos serviços nunca devem apagar as antigas injúrias" (Léry, I980: I84). ${ }^{5}$ Assim, se entregavam a guerras de vingança e, uma vez alcançada a vitória, de posse do inimigo abatido, "eles vêm triunfantes e destemidos preparar seus banquetes em sua terra" (Thevet, I953: I9I) Seu sentimento religioso era de outra natureza, não comportava os tormentos do medo com vistas a obter obediência e resignação: 
quando ribombava o trovão e nos valíamos da oportunidade para afirmar-lhes que era Deus quem assim fazia tremer o céu e a terra a fim de mostrar sua grandeza e seu poder, logo respondiam que se precisava intimidar-nos não valia nada (Léry, I980, 206-207).

O movimento antropofágico pilha e parodia, conforme anunciado pela poesia "Pau Brasil" (Andrade, 20 I Ib; 2003), a etnografia dos cronistas dos descobrimentos, tornando virtuosos os traços ali reconhecidos como aberrantes e desprezíveis. Católicos ou protestantes, por vezes complacentes ao denunciar o barbarismo de atos praticados por europeus, não se furtaram a conceber a inferioridade daqueles povos que não conheciam a escrita e não reverenciavam o Deus único e onipotente. Acreditados ateus, pecadores, convinha sobretudo revelar-lhes as luzes da fé cristã, para que pudessem verdadeiramente constituir uma comunidade íntegra e humana. Empresa malsinada, contudo, surpreendidos os atores pela valentia de sua reação, por sua obstinação em preservar a autonomia no processo de elaboração dos costumes, das relações sociais. Incoercíveis, indiferentes ao dogma, acatavam as prédicas jesuítas tão prontamente quanto as olvidavam, submetidos à natureza de uma alma inconstante (Viveiros de Castro, 20I I).

Mas, conforme adverte o movimento antropofágico, o legado tupi havia sido olvidado ou restava latente em certas atitudes e experiências culturais do brasileiro, enquanto um simulacro de nação se erguia à sombra das tradições decrépitas da Europa civilizada. Carecia recuperá-lo, em um cenário propício ao advento de uma nova era utópica, com o acirramento do avanço técnico e o declínio dos códigos morais do Ocidente. No Velho Mundo, agonizava o "europeu super-degenerado pela civilização", patente seu "desespero", "levado a esse estado de exacerbação por vinte seculos de superstição teologica", expressão de "uma crise de fato angustiosa, uma correspondencia natural das reações que no seu organismo produzira a maleita católica" (Moquem, I975a). A independência política havia sido, ao menos formalmente, conquistada, mas o Brasil permanecia submisso ao complexo cultural trazido pelas caravelas. "A nossa independencia ainda não foi proclamada. [...] Expulsamos a dynastia. É preciso expulsar o espírito bragantino" (Andrade, I975a: 7). A antropofagia surge como o impulso de rebeldia, haurido da cosmovisão indígena, contra a persistência das amarras da moralidade ocidental. A agressividade aflorando para quebrar ídolos, destruir e absorver tabus, único meio para o homem reencontrar sua natureza, recobrar sua liberdade originária. Na eterna alvorada da humanidade, o selvagem conservava, com sua alta compreensão da vida, a pureza e a ingenuidade que o tornavam imune aos artifícios dos povos ditos cultos, cuja operação essencial consiste em fazer a ciência e o sagrado coincidirem com o inacessível, o transcendente.

O indio não tinha o verbo sêr. Dahi ter escapado ao perigo metafisico que todos os dias faz do homem paleolitico um cristão de chupeta, um maometano, um budista, emfim um animal moralizado. Um sabiozinho carregado de doenças (De antropofagia, I975a). 
Fonte de padecimentos, a ética da obediência obstrui a percepção de estados de alegria e prazer, justificando a exortação radical: "Contra a moral convencional, moral nenhuma. O problema do Europeu desesperado é não sofrer. O nosso é gosar" (Guerra, I975). A existência como negatividade declina ante as investidas da cultura antropofágica e os abalos decorrentes do alvorecer de uma nova era.

A antropofagia acredita testemunhar o ápice do processo de dissolução dos alicerces da civilização ocidental. O esplendor das conquistas técnicas ameaça a exploração capitalista do trabalho, enquanto a subversão das formas tradicionais de união familiar corrói o instituto da herança, perpetuador das desigualdades, em meio ao desgaste da reputação da moralidade cristã. "O pater familias e a creaçao da Moral da Cegonha” (Andrade, I975a: 7) não encontram mais respaldo em uma sociedade "onde ninguém mais procura ser pai, esposo, filho" (Andrade, 20Iıa: ir8). Ademais, a mecanização faz avançar os dias "em que, no dizer de Aristóteles, 'os fusos trabalham sozinhos'” (Andrade, 20 I Ia: I45), tornando despropositada a faina humana escravizadora. A existência deixa de coincidir com o labor extenuante e a renúncia, perde a qualificação de mero trânsito, noção referendada na crença messiânica no advento de um reino celeste afortunado. Amanhece a esperança de libertação, de realização de uma comunidade terrena feliz e fraterna. O horizonte vaticina a derrocada do chamado "Patriarcado", dimensão social do civilizado monogâmico, recanto do filho de direito paterno, agasalhado nas malhas jurídicas do Estado classista e da propriedade privada. Na perspectiva antropofágica, o cenário catastrófico de crise do Ocidente, de tonalidade spengleriana (Splenger, I99I) ou inspirado em Keyserling (I929), deixa de abrigar um sentido trágico de decadência da cultura elevada, transposto em epílogo de um processo de reconciliação do homem a uma condição de liberdade. O mundo que nasce impulsionado pelo "bárbaro tecnizado", símbolo do avanço da técnica devastadora da tradição (Keyserling, I929), acaba se revelando o despontar de uma nova Idade de Ouro. A profecia de Spengler do declínio da Europa ocidental parece não tardar em ser cumprida, embora não seja tão pertinente supor que "o homem fáustico se tornou o escravo de sua criação" (Spengler, I99I: 4I2; grifos do autor) Ao contrário, o futuro utópico parece despontar; o vulto de um tempo venturoso é divisado:

No mundo supertecnizado que se anuncia, quando caírem as barreiras finais do Patriarcado, o homem poderá cevar a sua preguiça inata, mãe da fantasia, da invenção e do amor. E restituir a si mesmo, no fim do seu longo estado de negatividade, na síntese enfim, da técnica que é civilização e da vida natural que é cultura, o seu instinto lúdico. Sobre o Faber, o Viator e o Sapiens, prevalecerá então o Homo Ludens (Andrade, 20Ira: I45-I46).

Para a antropofagia, Pindorama foi o reduto ultramarino da utopia das formas de vida regidas pelo princípio materno. O indígena brasileiro, "nu, polígamo e ocioso", (Andrade, 20 I d: 308) vivia "em estado epicúreo" (Andrade, 
20I Ig: 3I7). Habitava as matas "feliz, sem letras, sem leis nem reis" (Moquem, I975a) e tampouco "era aristocrata, nem burguez, nem classe baixa" (Porque como, I975). Compreendia uma "humanidade pelada e livre que se entregava sem a menor repressão à gula natural de seus instintos sexuais" (Andrade, 20 I If: 400). Em seu seio, a personalidade não era constituída à sombra da imagem tirânica e repressora do pai, operando sobre o adolescente o "senso do Superego tribal" (Andrade, 20 I Ia: 200), entregues os filhos, primordialmente, ao grupo social. Ocorre que, origem do instituto do parentesco matrilinear, a procriação se desvencilha do amor. Este "é por excelência o ato individual, e seu fruto pertence à tribo" (Andrade, 20 I Ia: I52). Igualmente a terra, acolhida e reverenciada como patrimônio natural ou força cósmica, e cuja ocupação evoca a vigência da ideia de propriedade coletiva ou bem público, inconcebível sua partilha arbitrária, sua posse para usufruto privado. Em um tal reino da igualdade, ausentes os privilégios de classe auferidos por meio da exploração, da imposição do trabalho servil, resulta infundada a edificação de um aparato institucional coercitivo para o exercício da dominação política. O direito natural preside as relações sociais, segundo seus postulados de justiça, diverso do direito legislado do civilizado, objetivação do "que negava, pela coação, a própria natureza do homem" (Andrade, 20 I a: I42). Prevalecem as prerrogativas da dita "economia do ser", em contraposição à "economia do haver" patriarcal, ancorada no dinheiro e favorecedora da ambição do lucro e do acúmulo de riquezas. Os povos matriarcais, por sua vez, se organizam em torno de um sistema amonetário, radicado na troca, animado por um "espírito dadivoso, desprevenido e mesmo pródigo" (Andrade, 20 I I e: 420), correlato à justa distribuição dos bens. Obviamente, incide o fascínio instintivo desprendido ao contato com o colorido das pedrarias e metais reluzentes, preciosos, mas desacompanhado de uma visada mercantil, na verdade recolhidos para atender ao desejo financeiramente inócuo, cerimonial, de ostentação, pois "antes de promover o acúmulo de tesouros como riqueza o homem o faz tendo em vista a posse de adornos valiosos e duradouros" (Andrade, 201 I e: 4I7). Trata-se, portanto, de um gesto investido de significação eminentemente simbólica, tangenciado pelo sagrado e referido a uma dimensão da personalidade percorrida por impulsos primitivos de demonstração de poderio e pujança, externados na forma da posse de recursos para mera fruição ou usura irrefletida:

no inconsciente, as joias, como os excrementos, são matérias malditas que vertem de uma ferida partes em si mesmas destinadas a um sacrifício ostensivo (elas servem, na verdade, como presentes suntuosos carregados de amor sexual) (Bataille, 1967: 29).

A "moral do dom" orienta a circulação de bens, cujo valor corresponde à porção de prestígio, de honra que comunicam, originando um tipo de permu- 
ta solene e pautada por preceitos de generosidade, consubstanciada em atos de dissipação encetados com o fito de estabelecer laços de comunhão por meio da exibição de signos de altivez e glória. Sob a emergência de "um estado de perpétua efervescência econômica", "excedentes muito grandes, por assim dizer, são acumulados; eles são frequentemente gastos de forma inútil, com um luxo relativamente enorme e que não tem nada de mercantil" (Mauss, 200I: 266-267).

Entretanto, a empresa marítima e colonizadora ibérica teria destruído irremediavelmente aquela utopia realizada, esquecida nas latitudes misteriosas do continente ignoto. Debalde procurar restaurá-la, embora restasse, latente, o substrato ancestral da cultura nativa, identificado ao instinto bárbaro de agressividade, uma vez revivificado, capaz de originar as condições para a ascensão de um novo matriarcado no mundo contemporâneo. Pois, o índio "dorme, ás vezes, na floresta emaranhada do nosso sub-consciente, amoitado entre os cipós dos nossos nervos, mas existe ainda" (Campos, I975). Por outro lado, paradoxalmente, a descoberta do Novo Mundo abalou o patriarcado, ao desencadear um surto de transformações no plano dos referenciais valorativos de interpretação do homem e da vida, em função da divulgação dos cenários da sociedade primitiva. O episódio abriu um ciclo utópico, sob o arrebatamento, o aturdimento provocados pela visão paradisíaca de uma comunidade feliz na terra, que repercutiu na obra dos humanistas e corroeu a cosmologia corrente, a teodiceia cristã calcada na esperança do advento do reino espiritual divino esplendoroso. É quando "a Europa abre os olhos para o homem natural, 'sem culpa nem redenção', e ruma para os horizontes atlânticos, tomada de um novo conceito de vida", fazendo do século XVI, "um século libertino e revolucionário" (Andrade, 20 I I c: 252). No fundo, "a humanidade insiste, sem saber, em se matriarcalizar" (Andrade, 20 I Ic: 278). Embora a marcha irremediável e impositiva da civilização do "negócio", geradora da técnica, naquele tempo seguisse percorrendo seus caminhos, impulsionando as engrenagens do progresso material. Um tanto alheio a essas contingências, o Brasil permanecia a terra promissora do ócio, refugando a ética do trabalho protestante, feito coroado na vitória sobre os holandeses invasores do litoral nordestino. Ademais, a colonização perpetrada segundo o espírito aventureiro do português arabizado havia semeado a miscigenação benfazeja, sob um rastro de cultura poligâmica e de nomadismo, prefigurando uma nação composta de "raças matriarcais": "O Brasil compusera-se de raças matriarcais que não estavam distantes das concepções libertárias de Platão e dos sonhos de Morus e de Campanella" (Andrade, 20 I IC: 270). Aquelas regiões tropicais da América constituíam uma fronteira utópica, abrigando os germes de um novo matriarcado.

Segundo a perspectiva antropofágica, a ruína definitiva do patriarcado, prenunciada pela própria decrepitude e anacronismo da cultura civilizada na contemporaneidade, decorreria da eclosão violenta das forças matriarcais, em 
conjunção com as virtualidades do espraiamento do avanço técnico pelo mundo. Urgia reativar o instinto antropofágico de agressividade recalcado, mas sempre resistente nas práticas e expressões consideradas autênticas da cultura nacional, para o combate triunfal contra os esquemas vigentes de dominação moral e política. Assim, revigorada na seara de seus impulsos primários, apossando-se estrategicamente das realizações do progresso tecnológico, acatando a mecanização do trabalho para melhor desfrutar o ócio vital, a malta de bárbaros "tecnizados" seria a vanguarda da humanidade emancipada. Sua imagem refulge no episódio de encerramento do livro Serafim Ponte Grande (Andrade, 2007), expressão literária mais representativa do movimento antropofágico, por encerrar em suas páginas as expressões mais características da cosmovisão e dos valores constitutivos de seu conteúdo programático. O livro conta as peripécias do herói- protagonista e de seu dito secretário, José Ramos Góes Pinto Calçudo, perfazendo um itinerário de descobertas investido de um sentido de libertação por meio de atitudes e comportamentos subversivos em face das regulações impostas pelo conjunto das convenções sociais. As aventuras encenadas pelos personagens exprimem um rechaço, sobretudo um desdém, aos valores e instituições correntes, traduzindo uma experiência marginal de construção do cotidiano. Trata-se de verdadeiros antropófagos, totemizando tabus e absorvendo o ambiente, no caso especialmente a cidade moderna, para torná-lo favorável à satisfação de demandas naturais humanas. Os instintos sexuais passam a encontrar plena vazão, libertos de esquemas disciplinares normalizadores, em um tempo cada vez mais sob o impacto da desagregação dos fundamentos patriarcais e católicos da família. Há uma celebração do ócio lúdico e criativo, consoante a uma desqualificação zombeteira dos emblemas agonizantes da cultura ocidental. O legado caraíba e as contingências históricas de uma nova era exigem e propiciam um processo mais inventivo de individuação, operado pelo gesto de transgressão radical dos códigos morais que consuma uma carnavalização da existência, sob o signo da inconstância, da transitividade permanente, algo como um "devir utópico - a sociedade antropofágica, livre e redenta, perpetuamente 'aberta' em razão de sua própria mobilidade” (Campos, 2007: 43).

Já nas partes finais do livro, após retornar ao Brasil de suas andanças pela Europa e pelo Oriente, o herói Serafim retoma seu canhão e volta a ameaçar a ordem do alto de um arranha-céu. Encurralado pela polícia, sob aplausos da multidão satisfeita, se apropria das forças da natureza, pois, alçando um para-raios à cabeça, capta a descarga elétrica de uma tempestade repentinamente formada e termina fulminado, envolto em "um escuro de Mártir do Calvário" (Andrade, 2007: I94). Mas eis que, de alguma forma, Serafim ressurge, ressuscitado na figura do personagem Pinto Calçudo, portador de seu legado de rebeldia e anarquismo. A bordo do navio El Durazno, deflagra a revolução serafiniana, radical e de forte sentido transgressor: põe em curso um plano outrora idealizado, "a experiência de um mundo sem calças sobre a solidão chispada que agora 
salgavam milhas fora da projeção econômica das alfândegas" (Andrade, 2007: 204). Aproveitando as condições favoráveis, "no balão largado das auroras americanas", a tripulação aconchavada "em pelotão freudiano" (Andrade, 2007: 205) decreta a abolição das convenções morais, convertido o navio em uma ilha. "E instituiu-se [...], base do humano futuro, uma sociedade anônima de base priápica" (Andrade, 2007: 205). Sem rumo e sem dono, o transatlântico singra a superfície oceânica, cuja fluidez torna impraticável a vigência de uma normatividade verdadeiramente efetiva. Território insular perdido e mítico, como um dia se acreditou o paraíso tropical brasílico, abriga a experiência de reavivamento das práticas e da atitude do homem natural, devorador de tabus, agindo segundo os imperativos de suas demandas instintivas. A nudez desfaz os artifícios simbólicos que impedem a integração salutar com a realidade exterior. A existência adquire os contornos de uma festa, sob uma atmosfera orgiástica, suspensos os códigos estabilizadores do comportamento previsível e rotineiro. A promiscuidade medra, uma vez possibilitada a vivência plena da sexualidade em um ambiente de liberdade irrestrita. Prevalece o gesto espontâneo e imaginativo, filho do ócio propiciado pela ação da máquina, cintilando o éthos primitivista "ante a cópula mole e geométrica dos motores" (Andrade, 2007: 206). À deriva, em peregrinação indolente pelos vastos mares, a nave carnavalesca figura a "utopia da viagem permanente e redentora, pela busca da plenitude através da mobilidade" (Candido, 2008: 100). A alegoria de El Durazno encerra a imagem do matriarcado delineado no horizonte do mundo "tecnizado".

Parecem figurar seres liminares, esquecidos na transitividade oceânica, destituídos de signos de status, alheios a prescrições normativas, apartados da institucionalidade vigente. A espontaneidade de seus atos responde, sobretudo, a impulsos de satisfação imediata, em contraste com os requisitos de funcionalidade e previsibilidade, imprescindíveis ao equilíbrio e à permanência do conjunto de relações estruturadoras da vida social ordinária. Há uma dissolução de estereótipos, uma subversão de padrões de comportamento centrados nas noções de propriedade, família e tempo linear. Penetra-se numa espécie de limbo temporal, vivenciado como um eterno presente, "an eternal now" (Turner, I983: 238), imune às marcações cronológicas tradicionais. Um presente percebido como intervalo suspenso, no caso da antropofagia, concomitante a um passado imemorial e a um futuro utópico, convertido em dimensão sincrônica, em afronta à sequencialidade histórica. Benedito Nunes (20 I I: 39) se refere a uma concepção "transversal”, "uma compreensão da História absorvida na Pré-história, pelo que diz respeito ao passado, e dirigida a uma trans-história, pelo que diz respeito ao futuro". Na instabilidade de uma situação intermediária, marcada pela sobreposição de registros simbólicos ou mesmo pela ausência de referenciais fixos, a existência se torna menos pragmática e singularmente penetrada por um componente de ameaça, quando sobressai a vivacidade dos movimentos e das expressões ditados pelo improviso e pela imaginação criadora. Na verdade, 
tudo escapa a formas precisas, se mostra arredio a uma unidade acabada, o desregramento, o êxtase, as manifestações do amor "ilícito" (Turner, I979: I57), as emanações de poderes ctônicos e de energias animalescas (Turner, I983: 239, 253) evocando a vigência de uma condição extraordinária, precária, de alguma maneira tocada pelo sagrado.

A face utópica do discurso antropofágico transparece na denúncia e na negação da iniquidade e do caráter opressivo da ordem vigente. O presente se torna um tempo de degradação da vida e das relações humanas, devendo ser superado. Evocam-se imagens de uma sociedade ideal, prestes a se realizar sob a forma de um novo matriarcado, calcada em formas de convívio e valores contrastantes com as estruturas sociais existentes. Imagens, dessa maneira, dotadas de um forte componente analítico e de crítica da realidade. Há, portanto, uma convergência com certos traços distintivos dos escritos utópicos, como a narrativa paradigmática de Thomas More (2004), que afinal legou o termo utopia. "Todo pensamento utópico tem um elemento de fantasia, de sonho, ou pelo menos de anseio, de uma vida melhor e de um mundo melhor" (Finley, I989: I93). More (2004: I 27) forjou justamente a cidade ideal, como um não lugar feliz, sob a égide da liberdade e da igualdade, ausentes a economia monetária e a propriedade privada. Terra "onde tudo é comum a todos" e onde a riqueza é "levar uma existência alegre e pacífica", embora sob o peso das leis que imprimem um controle estrito da conduta. Na ilha de Utopia, todos devem se dedicar ao trabalho, cabendo às autoridades "zelar para que ninguém fique na ociosidade, e que todos exerçam seu ofício de maneira conscienciosa" (More, 2004: 57). Por seu turno, as relações conjugais são incisivamente reguladas: o sexo antes do casamento é proibido, e o adultério punido com a escravidão. A utopia antropofágica, contrariamente, não se manifesta por meio de uma ética do trabalho condenatória do ócio, tampouco por um aparato legal severo e formas de vigilância das ações e do comportamento humano. As propensões utópicas da humanidade, e especialmente do brasileiro, manifestam o afloramento ou o império da cultura matriarcal, justamente permissiva ao ócio e à liberdade sexual, tornados vetores de uma existência lúdica, criativa e feliz.

O matriarcado oswaldiano se assemelha ao "heterismo" de Bachofen (I973), era primordial, anterior à própria gênese das instituições derivadas do direito materno. ${ }^{6}$ Reino da promiscuidade, refratário a qualquer regulação das relações sexuais, distante dos códigos estabilizadores da união conjugal calcados no matrimônio.7 O gênero humano se encontra sob as emanações de Afrodite e em comunhão estrita com as leis da natureza. O telurismo prevalecente, indício da dominância do princípio maternal, corresponde ao simbolismo inspirado nas formas de vida vegetal e animal mais rudes, selvagens, imunes mesmo à interferência modeladora da agricultura. Um cenário favorecedor do nomadismo, portanto, onde nem a domesticação do cultivo operava como fator de fixação de comunidades em um determinado território. Paira "a fragilidade da existência 
telúrica" (Bachofen, I973: 9I), tomada em sua essência material e corporal, sem apelo ao plano espiritual ou ao transcendente luminoso, signos da ascensão do patriarcalismo uraniano, quando "o esforço e o sofrimento da vida prometeica tomam o lugar do descanso perpétuo, do gozo pacífico e da infância eterna em um corpo que envelhece" (Bachofen, I973: I Io). Eram os apanágios da cultura feminina que grassou nos confins do barbarismo ctônico, conferindo primazia ao lado esquerdo.

Costumes e práticas da vida religiosa e civil, peculiaridades de traje e acessórios para a cabeça, e certos usos linguísticos revelam a mesma ideia, a major honos laevarum partium (a honra maior do lado esquerdo) e sua estreita conexão com o direito materno" (Bachofen, I973: 77; grifos do autor).

Dimensão cósmica que acolhe as vibrações da vida profana, hauridas da terra, dotadas de impureza e instabilidade. Assomam as forças provindas das regiões inferiores, infernais, cujo sopro trevoso semeia ruína e morte. Enredadas na noite, carregam o estigma do torto, do obscuro e sacrílego, constitutivas de uma condição contraditória ou mesmo caótica: "signo de uma natureza contrária à ordem, de uma disposição perversa e demoníaca” (Hertz, I970: IOI). Sob seu domínio, vigoram a fraude, o engodo, a traição. Sua natureza feminina comunica fraqueza, é investida dos traços característicos de passividade e impotência. Oposto, o lado direito é o reino do sagrado sublime, imerso na claridade celeste, fonte de toda manifestação de equilíbrio, abrigo das virtudes do comedimento e da bondade. Universo diáfano receptivo à prevalência das qualidades de virilidade, altivez, nobreza, inerentes ao elemento masculino. Perpassa o fluxo criador divino que infunde vida, vigor físico e beleza aos seres, além de conferir um sentido harmônico à ordem social. Contudo, o esquerdo antropofágico irradia um brilho solar, proveniente das latitudes tropicais, liberto da nódoa vertida de uma pretensa substância mortificadora. Um feminino viril o anima, guerreiro, pleno de vitalidade, dominador. O caos, a irregularidade das formas fugidias, os movimentos escusos, todas as emanações do "baixo corporal" e cósmico, projetados na efusão da hybris festiva, se revelam um princípio fecundante, se tornam sagrados.

O rasto de Dioniso tinge o solo matriarcal. Inventor do vinho, comunica delírio e êxtase aos seus iniciados, proporcionando um desprendimento catártico das atribulações da vida cotidiana. Peregrino, campeia sem destino, sempre estrangeiro no território onde misteriosamente se manifesta. "Deus nômade, seu reino não tem sede" (Detienne, I988: 8). Seu culto celebra uma divindade ctônica, permeado pelas contingências do mundo físico, do elemento material, e recorrendo ao enlevo dos sentidos para alcançar eficácia. Envolto em uma simbologia fálica, percorre as fronteiras do erótico, instiga o sensualismo carnal, sintomas de um conluio com o princípio feminino. 


\begin{abstract}
Com sua sensualidade e ênfase no amor sexual, ele apresentava uma afinidade pronunciada com a natureza feminina e sua atração era principalmente por mulheres [...]. Dioniso é um deus da mulher no sentido mais pleno da palavra, a fonte de todos os desejos transcendentes e sensuais da mulher, o centro de sua completa existência (Bachofen, I973: IOI).
\end{abstract}

O excesso, a licença sexual, a inversão, peculiares ao ritual báquico, o tornam aliado das uniões e do comportamento espontâneos vigentes no contexto do naturalismo "hetárico", contrários à emergência de práticas sociais hierarquizantes e coercitivas. "Os antigos consideravam emancipação política e carnal irmãos gêmeos inseparáveis. A religião dionisíaca representava a apoteose tanto do prazer 'de Afrodite' como da fraternidade universal" (Bachofen, I973: I02). Assoma o barbarismo dionisíaco expresso na embriaguez alegre, por meio da qual "o subjetivo se esvanece em completo autoesquecimento" (Nietzsche, I992: 30). "O desmedido revelava-se como a verdade; a contradição, o deleite nascido das dores, falava por si desde o coração da natureza" (Nietzsche, I 992: 4I; grifo do autor). Universo em conflito com a civilização apolínea erguida sobre os pilares do equilíbrio, da ordem harmônica, da razão. "Apolo, como divindade ética, exige dos seus a medida e, para poder observá-la, o autoconhecimento" (Nietzsche, I992: 40).

\title{
CONSIDERAÇÕES FINAIS
}

O matriarcado talvez possa ser compreendido como o componente de redenção da cultura antropofágica, delineado na forma de uma utopia realizável e vinculado ao sentimento religioso inerente ao ser humano. Oswald de Andrade (Andrade, 20I Ie: 376) o denominou sentimento órfico, um impulso irracional de adoração radicado no substrato instintivo do homem - "uma dimensão religiosa, ligada aos seus instintos e desenvolvida pelos seus reflexos". Figura mítica, de caráter multifacetado e obscura, o Orfeu que desponta, em alusões esparsas, nos escritos oswaldianos, é justamente o cultor de Dioniso, o profeta dos mistérios do mundo sobrenatural. Herói sem abrigo na morada olímpica, destinado a se precipitar às regiões infernais e tornar à superfície carregando seus segredos para comunicá-los, pelo canto, aos mortais. Peregrino das profundezas, instaurador de uma cultura religiosa mística praticada em torno de cerimônias iniciatórias e invocações, cujo fim é realizar a comunhão com deus e o sagrado. Rituais epifânicos promovem os estados de transe, o êxtase, efeitos da incidência de uma possessão divina que desencadeia uma transformação interior, abstraindo o indivíduo de sua personalidade, elevado do plano das atribulações cotidianas (Guthrie, I993). "Porque o sentimento órfico é, evidentemente, a dimensão louca do homem, sem a qual ele não vive e não se refaz dos golpes duríssimos do dia a dia" (Andrade, 20 I Ie: 394-395). Transparece 
se ergue natural e espontaneamente à superfície, uma vez que, na maioria dos corações dos homens, é um crescimento inato, não implantado (Guthrie, I993: I50).

Como uma manifestação instintiva, esse sentimento germina em meio às deambulações da vontade espontânea da criança, mergulhada "numa cálida inconsciência benéfica": "na infância se insere facilmente isso que eu batizei de sentimento órfico e que não passa do sentimento religioso" (Andrade, 20 I Ih: 455). Podendo ser traduzido como uma "vocação do homem para crer e adorar" (Andrade, I972: 226), um anseio de contato com os aspectos místicos da existência, encontra sua realização mais significativa nas expressões rituais e litúrgicas da experiência religiosa. Essa dimensão corresponde às autênticas propensões fideístas dos povos, enquanto a parte ética e dogmática representa uma construção artificial, arbitrária e repressora, imposta pelas autoridades eclesiásticas como sustentáculo para a garantia de suas prerrogativas espirituais e políticas. Propensão equivocadamente canalizada para as religiões confessionais, de salvação, assentadas na noção de parúsia. Oswald procura restaurar a validade de um órfico orgiástico, dionisíaco, vivenciado em torno de cerimônias festivas. Importa reavivar a cultura mística investida "do caráter orgiástico que tinha na Grécia (mistérios órficos, festas dionisíacas) e que se conserva ainda nos povos primitivos" (Andrade, 20 г га: I73). Fica obscurecida a face apolínea de Orfeu, identificada com um ideal de pureza e a observância a um severo código de conduta ascética como condição para alcançar imortalidade. O iniciado-antropófago faz o instinto religioso corresponder a um gesto individual e de afirmação da individualidade, de sentido emancipatório, sob as ameaças de um mundo condicionado pelo trágico e pelo conflito. "A necessidade de adoração que mora na alma do homem" (Andrade, 20 I Ig: 455), enquanto "fluxo de sentimento animal" (Andrade, 20 I Ie: 395), deixa de se atrelar à esperança de salvação por meio da renúncia e da negação da vida terrena para aderir às expressões do cotidiano, compondo o conjunto de relações sociais constitutivas de uma experiência utópica factível.

Recebido em 5/3/20I7 | Revisto em 8/8/20I7 | Aprovado em I3/I I/20I7 
Christian Bruno Alves Salles é bacharel em história pela Universidade Federal de Minas Gerais (UFMG) e doutor em sociologia pelo Instituto de Estudos Sociais e Políticos da Universidade do Estado do Rio de Janeiro (Iesp/Uerj). Atualmente é pesquisador do Centro de Estudos Republicanos Brasileiros (Cerbras) da UFMG. 


\section{NOTAS}

I Roberto Schwarz (I987) assinala o caráter triunfalista da interpretação antropofágica do atraso da sociedade brasileira. Para o autor, a desarmonia entre padrões burgueses e sobrevivências primitivistas, amiúde índice de um destino malsinado, é convertida em atributo positivo pelo discurso da antropofagia. O otimismo ainda se expressa pela possibilidade aberta de construção de uma trajetória histórica alternativa à burguesa, em função da assimilação das conquistas técnicas da modernidade ao fundo primitivista da nação, delineando os contornos de uma experiência utópica no Brasil. Todo esse quadro é qualificado de ingênuo e ufanista por Schwarz (I987: 38): "A distância no tempo torna visível a parte de ingenuidade e também de ufanismo nestas propostas extraordinárias." Talvez o termo ufanista não seja o mais adequado para se referir ao programa da antropofagia, por não me parecer estar no seu cerne uma exaltação cega e idílica de supostas virtudes superiores da nação, mas a identificação de um instinto nativo de agressividade que deve ser recuperado como condição para a deflagração de uma ruptura com estruturas normativas contrárias a uma existência mais lúdica e prazerosa. Por outro lado, o fato de o movimento antropofágico não recorrer à categoria classe como elemento propulsor de um processo revolucionário não constitui razão para classificar de ingênua sua proposta combativa, a qual está mesmo centrada no indivíduo e opera no plano dos referenciais simbólico-valorativos, sem, contudo, deixar de estar investida de alto teor subversivo e potencial transformador.

2 Esse ciclo utópico teria sido inaugurado, segundo Oswald de Andrade (20Ira), pelo impacto sobre as formas de interpretação do mundo provocado pela descoberta da América, tendo o Brasil como seu principal cenário e encontrando seu ápice naquele início de século, com a derrocada do modelo civilizacional ocidental, decorrente das inovações técnicas em curso - que tornariam o trabalho cotidiano desnecessário -, bem como da decadência da moralidade cristã e das formas tradicionais de organização da família.

3 Nessa e nas demais citações em idioma estrangeiro a tradução é livre. 
4 Fica justificada a "filiação" tanto a Montaigne como a Rousseau, proposta no Manifesto: "Filiação. O contacto com o Brasil Carahiba. Oú Villeganhon print terre. Montaigne. O homem natural. Rousseau" (Andrade, I975a: 3; grifos no original). Embora o discurso antropofágico não seja receptivo à noção idealizada do "bom selvagem", em boa medida derivada das formulações daqueles autores, cabendo indagar: "Que culpa temos de dizerem outros que copiamos Rousseau, quando foi Rousseau que tentou copiar o bom selvagem, sem aliás o conseguir?" (Moquem, I975b).

5 Conforme a formulação do Manifesto: "Tinhamos a justiça codificação da vingança" (Andrade, I975a: 7).

6 "Voltamos aos alimentos crus e à tatuagem cotidiana. A esposa moderna amanhece irreconhecível. Voltamos ao que na Grécia se chamou de hetairismo. Ao uranismo e outros baitolismos. Num já adquirido 'estado de inocência'” (Andrade, 2009: 2I4).

7 É igualmente considerável a influência de A origem da família, da propriedade privada e do Estado, cujas proposições se apoiam nas próprias pesquisas pioneiras de Bachofen, sobre a caracterização de Oswald do matriarcado e da cultura patriarcal, tributária do acento conferido por Engels à herança como instituto perpetuador da concentração da riqueza sob o patriarcado, e à identificação de uma idade primeva erigida em torno da propriedade comum da terra e do consórcio conjugal promíscuo, em um cenário em que "não se pode saber com certeza quem é o pai de uma criança" (Engels, I987: 43). "A monogamia nasceu da concentração de grandes riquezas nas mesmas mãos - as de um homem - e do desejo de transmitir essas riquezas, por herança, aos filhos deste homem, excluídos os filhos de qualquer outro" (Engels, I987: 82). 


\section{REFERÊNCIAS BIBLIOGRÁFICAS}

Andrade, Oswald de. (20Ira). A crise da filosofia messiânica. In: Andrade, Oswald de. Obras Completas: A utopia antropofágica. São Paulo: Globo.

Andrade, Oswald de. (20I Ib). Manifesto da poesia pau-brasil. In: Andrade, Oswald de. Obras Completas: A utopia antropofágica. São Paulo: Globo.

Andrade, Oswald de. (20IIC). A marcha das utopias. In: Andrade, Oswald de. Obras Completas: A utopia antropofágica. São Paulo: Globo.

Andrade, Oswald de. (20IId). Ainda o matriarcado. In: Andrade, Oswald de. Obras Completas: A utopia antropofágica. São Paulo: Globo.

Andrade, Oswald de. (20IIe). O antropófago. In: Andrade, Oswald de. Obras Completas: Estética e política. São Paulo: Globo.

Andrade, Oswald de. (20I If). Variações sobre o matriarcado. In: Andrade, Oswald de. Obras Completas: A utopia antropofágica. São Paulo: Globo.

Andrade, Oswald de. (20IIg). O achado de Vespúcio. In: Andrade, Oswald de. Obras Completas: A utopia antropofágica. São Paulo: Globo.

Andrade, Oswald de. (20I Ih). Do órfico e mais cogitações. In: Andrade, Oswald de. Obras Completas: Estética e política. São Paulo: Globo.

Andrade, Oswald de. (2009). O êxito na terra substituiu a esperança no céu. In: Andrade, Oswald de. Obras Completas: Os dentes do dragão. São Paulo: Globo.

Andrade, Oswald de. (2007). Obras Completas: Serafim Ponte Grande. São Paulo: Globo.

Andrade, Oswald de. (2003). Obras Completas: Pau-Brasil. São Paulo: Globo.

Andrade, Oswald de. (1975a) [1928]. Manifesto antropófago. Revista de antropofagia, I, primeira dentição. (Edição fac-similada, São Paulo: Abril).

Andrade, Oswald de. (1975b) [1928]. Schema ao Tristão de Athayde. Revista de Antropofagia, 5, primeira dentição. (Edição fac-similada, São Paulo: Abril). 
Andrade, Oswald de. (1972). Descoberta da África. In: Andrade, Oswald de. Obras Completas VI: Do pau-brasil à antropofagia e às utopias. Rio de Janeiro: Civilização Brasileira. Assumpto resolvido. (I975) [1929]. Revista de antropofagia, 9, primeira dentição. (Edição fac-similada, São Paulo: Abril).

Bachofen, Johann Jakob. (I973). From mother right. In: Bachofen, Johann Jakob. Mith, religion, and mother right. Princeton: Princeton University Press.

Bataille, Georges. (I967). La notion de dépense. In: La part maudite. Paris: Les Éditions de Minuit.

Caillois, Roger. (1979). La fête. In: Hollier, Denis (org.). Le Collège de Sociologie. Paris: Gallimard, p. 475-52I.

Campos, Haroldo de. (2007). Serafim: um grande não-livro. In: Andrade, Oswald de. Obras Completas: Serafim Ponte Grande. São Paulo: Globo.

Campos, Humberto de. (I975) [1929]. Confissão. Revista de Antropofagia, 9, segunda dentição. (Edição fac-similada, São Paulo: Abril).

Candido, Antonio. (2008). Oswald viajante. In: O observador literário. Rio de Janeiro: Ouro sobre Azul, p. 97-Ior.

Costa, Oswaldo. (I975) [1928]. Revisão necessária. Revista de Antropofagia, I, primeira dentição. (Edição fac-similada, São Paulo: Abril).

De antropofagia. (I975a) [I929]. Revista de Antropofagia, I, segunda dentição. (Edição fac-similada, São Paulo: Abril).

De antropofagia. (I975b) [I929]. Revista de Antropofagia, I4, segunda dentição. (Edição fac-similada, São Paulo: Abril).

Detienne, Marcel. (1988). Dioniso a céu aberto. Rio de Janeiro: Zahar.

Engels, Friedrich. (1987). A origem da família, da propriedade privada e do Estado. Rio de Janeiro: Civilização Brasileira.

Finley, Moses. (1989). Utopismo antigo e moderno. In: Uso e abuso da história. São Paulo: Martins Fontes.

Guerra. (I975) [1929]. Revista de Antropofagia, 4, segunda dentição. (Edição fac-similada, São Paulo: Abril).

Guthrie, William Keith Chambers. (1993). Orpheus and Greek religion. Princeton: Princeton University Press. 
Hertz, Robert. (I970). La prééminence de la main droite. Étude sur la polarité religieuse. In: Sociologie religieuse et folklore. Paris: Presses Universitaires de France.

Keyserling, Hermann von. (1929). Le monde qui nait. Paris: Librairie Stock.

Léry, Jean de. (I980). Viagem à terra do Brasil. Belo Horizonte: Itatiaia.

Lestringant, Frank. (I997). O canibal: grandeza e decadência. Brasília: Editora Universidade de Brasília.

Machado, Antônio de Alcântara. (1975) [1928]. Abre-alas. Revista de Antropofagia, I, primeira dentição. (Edição fac-similada, São Paulo: Abril).

Mauss, Marcel. (200I). Essai sur le don. Forme et raison de l'échange dans les sociétés archaïques. In: Sociologie et anthropologie. Paris: Presses Universitaires de France.

Montaigne, Michel de. (1996). Dos canibais. In: Ensaios, v.I. São Paulo: Nova Cultural.

Moquem. (1975a) [1929]. Revista de Antropofagia, 5, segunda dentição. (Edição fac-similada, São Paulo: Abril).

Moquem. (1975b) [1929]. Revista de Antropofagia, 7, segunda dentição. (Edição fac-similada, São Paulo: Abril).

More, Thomas. (2004). Utopia. Brasília: Ed. UnB.

Nietzsche, Friedrich. (1992). O nascimento da tragédia ou helenismo e pessimismo. São Paulo: Companhia das Letras.

Nunes, Benedito. (20II). Antropofagia ao alcance de todos. In: Andrade, Oswald de. Obras Completas: A utopia antropofágica. São Paulo: Globo.

O direito antropofágico. (1975) [1929]. Revista de Antropofagia, I3, segunda dentição. (Edição fac-similada, São Paulo: Abril).

Porque como. (I975) [1929]. Revista de Antropofagia, 6, segunda dentição. (Edição fac-similada, São Paulo: Abril).

Rezende, Garcia de. (I975) [I929]. A proposito do ensino antropofágico. Revista de Antropofagia, II, segunda dentição. (Edição fac-similada, São Paulo: Abril).

Rousseau, Jean-Jacques. (1997). Discurso sobre a origem e os fundamentos da desigualdade entre os homens, v. 2. São Paulo: Nova Cultural. 
Schwarz, Roberto. (1987). Nacional por subtração. In: Que horas são? São Paulo: Companhia das Letras.

Spengler, Oswald. (I99I). The decline of the West. New York/ Oxford: Oxford University Press.

Thevet, Andre. (1953). La cosmographie universelle. Paris: PUF.

Turner, Victor. (1983). Passages, margins, and poverty: religious symbols of communitas. In: Dramas, fields, and metaphors; symbolic action in human society. Ithaca: Cornell University Press.

Turner, Victor. (1979). Communitas: model and process. In: The ritual process; structure and anti-structure. Ithaca: Cornell University Press.

Viveiros de Castro, Eduardo. (20I I). O mármore e a murta: sobre a inconstância da alma selvagem. In: A inconstância da alma selvagem: e outros ensaios de antropologia. São Paulo: Cosac Naify. 
Palavras-chave

Modernismo brasileiro; movimento antropofágico; utopia; cosmovisão indígena; civilização ocidental

Keywords

Brazilian modernism; anthropophagic movement; utopia; Indian cosmovision Western civilization.

\section{A UTOPIA ANTROPOFÁGICA: RASTOS E HORIZONTES}

\section{Resumo}

O artigo analisa o conteúdo programático do movimento antropofágico argumentando que ele encerra uma proposta de emancipação do homem, frequentemente expressa por meio de imagens utópicas. De acordo com Oswald de Andrade, a experiência de vida do indígena brasileiro representou uma utopia fundada em uma cosmovisão centrada em ideais de liberdade e igualdade, experiência que foi, porém, irremediavelmente destruída pela empresa colonizatória portuguesa, sendo impossível e mesmo inoportuno restaurá-la nos dias presentes. Entretanto, pretende-se mostrar como, para a antropofagia oswaldiana, o impulso primário de agressividade, que inspira as ações do nativo, deve ser recuperado, em um contexto histórico de crise da civilização ocidental, favorável à emergência de uma nova era utópica.

\section{THE ANTHROPOPHAGIC UTOPIA: TRACES}

\section{AND HORIZONS}

\section{Abstract}

The article analyses the programmatic content of the anthropophagic movement, arguing that it contains a proposal for the emancipation of man, frequently expressed through utopian imagery. For Oswald de Andrade, the life experience of the Brazilian Indian represented a utopia founded on a cosmovision centred on the ideals of freedom and equality, an experience that was, however, irremediably destroyed by Portuguese colonization, making it impossible and even inopportune to restore it in the present. However, the aim is to show how, for Oswaldian anthropophagy, the primary impulse of aggression, which inspires the actions of the native, should be recuperated in a historical context of crisis in western civilization, favouring the emergence of a new utopian era. 